\title{
Review
}

Ophthalmologica

\section{Posturing after Macular Hole Surgery: A Review}

\author{
Aman Chandra $^{a}$ David G. Charteris ${ }^{a}$ David Yorston ${ }^{b}$ \\ ${ }^{a}$ Vitreoretinal Department, Moorfields Eye Hospital, London, and ${ }^{\mathrm{b}}$ Tennent Institute of Ophthalmology, \\ Gartnavel Hospital, Glasgow, UK
}

\section{Key Words}

Macular hole $\cdot$ Face-down posturing $\cdot$ Posturing $\cdot$

Vitrectomy

\begin{abstract}
Since the first reports on surgical repair of macular holes, postoperative face-down posturing (FDP) has been part of the management regime. However, prone positioning is unpleasant for patients, and has adverse effects. Over the last decade some vitreoretinal surgeons have reduced the duration of FDP, or even abandoned it altogether. There have been few non-randomised, and even fewer randomised trials addressing this controversy. With high success rates for macular hole surgery and multiple different surgical strategies such as internal limiting membrane peeling, combining macular hole and cataract surgery, and different durations of gas tamponade, analysing the effects of individual factors is difficult. This paper discusses the mechanisms of surgical repair as well as the role of postoperative FDP, and reviews the studies that have attempted to determine its effect on the success of macular hole surgery.
\end{abstract}

Copyright $\odot 2011$ S. Karger AG, Basel
(C) 2011 S. Karger AG, Basel

$0030-3755 / 11 / 2265-0003 \$ 38.00 / 0$

Fax +4161306 1234

E-Mail karger@karger.ch

www.karger.com
Accessible online at:

www.karger.com/oph

\section{Introduction}

Surgery to close macular holes developed from the necessity to manage retinal detachments associated with posterior pole breaks [1-3]. Although many advances have been made since those initial days, the concepts of vitrectomy and tamponade have remained. The early proponents of this technique introduced face-down posturing (FDP) postoperatively for their patients [3], with more defined periods of FDP being suggested subsequently $[4,5]$. This remained part of the treatment for macular holes for many years. However, FDP was first challenged in 1997 [6], and this debate still continues amongst retinal surgeons. This paper reviews what is known about the effectiveness of postoperative FDP for macular hole repair.

\section{Macular Hole Surgery}

Anteroposterior traction secondary to abnormally persistent vitreofoveal attachment, in combination with tangential contraction of the perifoveal vitreous cortex are thought to initiate macular hole formation [7-10]. The first series attempting to address this by removal of the

\footnotetext{
Aman Chandra

Vitreoretinal Department, Moorfields Eye Hospital

City Road

London EC1V2PD (UK)

E-Mail amanchandra@gmail.com
} 
posterior cortical hyaloid was by Kelly and Wendel [4] in 1991. The main aim of surgical intervention is to relieve traction and halt intraretinal hydration and the subretinal accumulation of vitreous fluid through the hole [11]. Core vitrectomy and removal of epiretinal membranes achieves this. In addition surgical intervention stimulates reparative healing mechanisms. It is thought that peeling the internal limiting membrane (ILM) reduces tangential traction by both removing residual vitreous cortex and any substrate for myofibroblast growth, which may contract and prevent closure of the hole [12]. ILM peeling may stimulate local glial repair by upregulating growth factors [13]. Although some groups have found no improvement in anatomical or visual outcome with ILM peeling [14], others have shown significant improvements [15-17]. Randomised controlled trials have shown a significantly higher macular hole closure rate with ILM peeling $[18,19]$.

The concept of tamponade developed from the first operations for macular hole closure [4]. Air tamponade was shown to be less effective than long-acting gases; Thompson et al. [20] showed a 97\% closure rate with $16 \%$ perfluoropropane $\left(\mathrm{C}_{3} \mathrm{~F}_{8}\right)$ compared with $53 \%$ with air. Other tamponades were suggested, particularly silicone oil, which had been used for macular hole retinal detachment repairs [21] with good anatomical outcomes. Primary macular hole closure with silicone oil tamponade reaches $80-97 \%$ [22-25]. Although some indicate better visual outcomes than with long-acting gas [22], others suggest visual outcomes are poorer with oil tamponade $[23,24,26]$. This may be due to oil toxicity, or may reflect selection bias in these retrospective series. The modes of action of tamponade include: providing a scaffolding for reparative glial tissue, particularly Müller cells and fibrous astrocytes, across the macular hole $[27,28]$; prevention of subretinal hydration with vitreous fluid ('macular isolation') [11]; maintaining a mechanical force to keep the macular hole against the retinal pigment epithelium, and opposing any tractional forces which may hold the hole open $[29,30]$. The actual effect of intraocular gases may lie in the fluid-gas surface tension rather than any buoyancy effect [31]. This is supported by the success of silicone oil, which has a greatly reduced buoyancy compared with gas tamponade [25].

\section{Why Bother with FDP?}

FDP has been considered an integral part of macular hole surgery. This is based on studies that have shown that short-term tamponades such as air [20] have significantly reduced success rates of closure. Indeed some au- thors have suggested that the longer the duration of gas tamponade, the better the results [30]. This principle of long action seems to hold true for silicone oil as a tamponade $[24,26]$, notwithstanding the poorer visual outcomes $[23,32]$. The effect of tamponade is thought to rely on contact between the tamponade agent and the reparative glial cells (thus 'isolating' the macula from vitreous cavity fluid). This is achieved by allowing maximal contact between the tamponade and the macula. Even though Foster and Chou [31] described the concept of a 'tolerance angle' within which enough of a break would be covered for surface tension to have its effect on closure, 'maximal coverage' may play a pivotal role in healing. They suggest that patients should be orientated such that the centre of a retinal break is at the highest point with respect to gravity for a tamponade agent to exert its maximal effect. This is true whether the mechanism of the tamponade effect is by buoyancy $[30,33,34]$ or surface tension [31]. For a macular hole, this would require face-down positioning.

\section{Disadvantages of FDP}

Posturing in the face-down position is difficult for patients. They are usually required to posture face down for between 45 and $55 \mathrm{~min}$ of every hour [35]. The total duration of posturing has been debated by many authors. Optical coherence tomography (OCT) studies have shown that flattening of retinal cysts and approximation of macular dehiscence can occur in macular holes of a size of less than $400 \mu \mathrm{m}$ by the first day postoperatively $[36,37]$. Muquit et al. [38] have recently shown sufficient gas-macula contact on Fourier domain OCT 1 day after surgery in the upright position. Eckardt et al. [39] analysed 33 consecutive cases which included 9 stage IV holes. These cases did not undergo ILM peeling and were tamponaded with air. Their FDP was determined by close OCT monitoring. The authors were able to stop FDP after $24 \mathrm{~h}$ in $54 \%$ of their cases as the holes were closed; $90 \%$ of their cases had OCT-proven closed macular holes after 3 days. The same group has recently shown that $79 \%$ of macular holes in a larger cohort of 112 patients with air tamponade closed within 3 days [40]. The authors questioned the need for lengthy periods of FDP. Krohn [41] showed no significant visual or anatomical differences between 7 and 3 days of posturing. However, there seems to be no pattern in patients who failed to have their macular holes closed after shortened periods, thus making it difficult to predict those who may need longer FDP.

Patients may be reluctant to endure FDP [42]. Shoulder and neck discomfort, and the psychological morbidity re- 
sulting from isolation and boredom secondary to FDP, may prevent patients from complying with FDP. It may even deter them from having macular hole surgery in the first place [43]. One paper suggested that $54 \%$ of patients found FDP for 5 days difficult [44].

Waterman et al. [45] suggest that significant training is required to improve nursing input into FDP, and thus patient compliance. Unsurprisingly, patients prefer not to undergo FDP [46]. Furthermore, compliance with FDP is poor [47]. Verma et al. [47] designed a device to digitally record the head position, and applied this to patients after macular hole surgery. Although not detailed, the $10 \mathrm{pa}-$ tients in this study had to follow a 'strict head down posturing regime'. This small group maintained their head posture as instructed for only $38 \%$ of the time. This suggests that even when patients are instructed to maintain strict FDP, this is rarely achieved in practice.

FDP is not free of complications. It may interfere with postoperative topical medication administration, which may affect the final closure rate [48]. FDP has been associated with acute angle-closure glaucoma in the fellow eye. [49] Excessive posturing may lead to complications such as ulnar nerve palsies [50] and pressure sores [51]. It is against the backdrop of these controversies that the requirement for FDP has been questioned.

\section{Publications Analysing FDP}

Although the evidence for FDP is conflicting, there is widespread agreement that ILM peeling promotes hole closure based on both non-randomised $[14,15,52]$ and randomised trials $[17,18]$. It may be particularly important in larger macular holes [53]. We have divided comparative studies of FDP into those that incorporated ILM peeling and those that did not.

Because closure of the hole may occur within a few days of surgery, there is uncertainty regarding the duration of any FDP. A few authors compared differing lengths of FDP. It should be noted that in the context of high anatomical success rates, the case numbers of studies are relatively small.

\section{Studies Analysing Shortened FDP with ILM Peeling}

Dhawahir-Scala et al. [54] reported a small non-randomised observational trial comparing 20 patients who were advised to posture face down for $24 \mathrm{~h}$ only with 8 patients who were advised to maintain FDP for 10 days after phacovitrectomy with ILM peeling. The patients were reviewed finally at 6 weeks. The macular hole clo- sure rates were $20(100 \%)$ of the non-postured group compared with 7 (87.5\%) of the postured group. Postoperative $\log$ MAR (logarithm of the minimum angle of resolution) visual acuity was $0.42 \pm 0.19$ for macular holes of $<12$ months duration, and $0.65 \pm 0.16$ for $>12$ months duration. This compared with $0.41 \pm 0.28(<12$ months) and $0.65 \pm 0.16$ in the postured groups. Patients were examined 1 day postoperatively, and if the gas fill was above the inferior arcade, they were asked to undergo FDP. This poor fill may have compromised the closure rate in these patients. However, this does perhaps illustrate the beneficial effect of FDP in eyes with a poor gas fill.

\section{Studies Analysing Shortened FDP without ILM Peeling}

Krohn [41] analysed 29 patients who were advised to keep FDP for 7 days compared with 24 patients who were advised to keep FDP for 3 days. No patients underwent ILM peeling. Twenty-one (93.1\%) of the 7-day cohort had closed macular holes after 6 months of follow-up compared with 21 (87.5\%) of the 3-day group. His cohort comprised mostly stage III holes, with 9 stage IV holes. Krohn suggests that 3 days of FDP may be sufficient.

Isomae et al. [55] compared 34 eyes of 33 patients who were instructed to maintain FDP for 1 week with 21 eyes of 21 patients who were advised to maintain FDP for $24 \mathrm{~h}$. No patients had ILM peeling. The authors reported hole closure in 31 (91.2\%) of the 1-week cohort compared with 19 (90.5\%) of the 24-hour cohort. One of the limitations of this study was that the two groups were not concurrent. There was also a greater proportion of stage IV holes in the 1-week group.

\section{Studies Analysing No FDP with ILM Peeling}

Tornambe et al. [6] published the first report on macular hole surgery without FDP. They analysed 33 consecutive cases who, if phakic, underwent combined cataract extraction, intraocular lens insertion and macular hole surgery (including epiretinal membrane peeling and, if possible, ILM 'scratching'). They reported a closure rate of $79 \%$ after 1 surgery, and of $85 \%$ after 2 surgeries. They had a heterogeneous consecutive group of patients, with $88 \%$ of the holes being graded as stage III or IV and $21 \%$ of the holes being present for over 1 year. The authors were the first group to suggest that FDP may be eliminated with combined phacovitrectomy and complete fill of the posterior cavity with $\mathrm{C}_{3} \mathrm{~F}_{8}$ since there have been numerous reports of successful outcomes with limited or no FDP $[56,57]$, but few comparative trials. 
Table 1. Studies with a control arm (FDP) compared with no FDP after macular hole surgery

\begin{tabular}{|c|c|c|c|c|c|c|c|c|c|}
\hline $\begin{array}{l}\text { First } \\
\text { author }\end{array}$ & $\begin{array}{l}\text { Date of } \\
\text { publi- } \\
\text { cation }\end{array}$ & $\begin{array}{l}\text { FDP } \\
\text { controls }\end{array}$ & $\begin{array}{l}\text { Number in each } \\
\text { arm }\end{array}$ & $\begin{array}{l}\text { Grade/size } \\
\text { of holes }\end{array}$ & $\begin{array}{l}\text { Combined } \\
\text { cataract } \\
\text { surgery }\end{array}$ & Tamponade & $\begin{array}{l}\text { ILM/ERM } \\
\text { peeling }\end{array}$ & $\begin{array}{l}\text { Adjuvant } \\
\text { therapy }\end{array}$ & Findings \\
\hline Simcock & $2001[58]$ & Historical & $\begin{array}{l}20 \text { non-FDP } \\
\text { cases vs. } 13 \text { FDP } \\
\text { controls }\end{array}$ & $\begin{array}{l}13 \text { stage II; } \\
7 \text { stage III; } \\
\text { similar \% in } \\
\text { controls }\end{array}$ & Yes & $\mathrm{C}_{2} \mathrm{~F}_{6}(80 \%$ fill $)$ & ILM & No & $\begin{array}{l}18 \text { out of } 20(90 \%) \\
\text { closure rate in non-FDP } \\
\text { group }(11 / 13,85 \%, \text { in } \\
\text { controls); } 19 / 20(95 \%) \\
\text { improved VA by } 0.3 \text { logMAR } \\
\text { in non-FDP group ( } 69 \% \text { in } \\
\text { controls) }\end{array}$ \\
\hline Tranos & 2007 [59] & $\begin{array}{l}\text { Each arm } \\
\text { allocated at } \\
\text { the different } \\
\text { study sites }\end{array}$ & $\begin{array}{l}16 \text { non-posture } \\
\text { vs. } 25 \text { FDP }\end{array}$ & $\begin{array}{l}85 \% \\
\text { grade II/III; } \\
15 \% \\
\text { grade IV }\end{array}$ & No & $\mathrm{C}_{3} \mathrm{~F}_{8}$ & $\begin{array}{l}\text { ILM } \\
\text { (dye } \\
\text { assisted) }\end{array}$ & No & $\begin{array}{l}14 / 16(87.5 \%) \text { anatomical } \\
\text { closure in non-FDP group } \\
(22 / 25,88 \% \text {, in FDP } \\
\text { controls); increased cataract } \\
\text { rate in non-FDP group }\end{array}$ \\
\hline Guillaubey & $2008[60]$ & Randomised & $\begin{array}{l}72 \text { seated vs. } \\
78 \text { FDP }\end{array}$ & $\begin{array}{l}53 \% \\
>400 \mu \mathrm{m}\end{array}$ & $\begin{array}{l}\text { Mixed: } \\
\text { yes }(41 \%) \\
\text { no }(59 \%)\end{array}$ & $\begin{array}{l}\text { Depending on } \\
\text { size of } \mathrm{MH} ; \\
\mathrm{SF}_{6}(20 \%) \text { : } \\
<500 \mu \mathrm{m} ; \\
\mathrm{C}_{2} \mathrm{~F}_{6}(17 \%) \text { : } \\
500-800 \mu \mathrm{m} ; \\
\mathrm{C}_{3} \mathrm{~F}_{8}(14 \%): \\
800-1,000 \mu \mathrm{m}\end{array}$ & $\begin{array}{l}\text { ILM } \\
\text { (no dye) }\end{array}$ & No & $\begin{array}{l}31 / 39(79.5 \%) \text { anatomical } \\
\text { closure with } \mathrm{MH}>400 \mu \mathrm{m} \\
\text { in non-FDP group }(39 / 41 \\
95.1 \% \text {, in FDP group; } \\
\left.\mathrm{p}=0.045^{1}\right)\end{array}$ \\
\hline Tadayoni & $2011[62]$ & Randomised & $\begin{array}{l}35 \text { no FDP vs. } \\
34 \text { FDP }\end{array}$ & $<400 \mu \mathrm{m}$ & $\begin{array}{l}5 \text { patients: } \\
\text { combined } \\
\text { surgery }\end{array}$ & $\mathrm{C}_{2} \mathrm{~F}_{6}(17 \%)$ & No & No & $\begin{array}{l}32 / 35(91.4 \%) \text { hole closure in } \\
\text { non-FDP group }(32 / 34, \\
94.1 \% \text {, in FDP group) }\end{array}$ \\
\hline
\end{tabular}

$\mathrm{MH}=$ Macular hole; VA = visual acuity.

${ }^{1}$ Interpreted as statistically significant.

Simcock and Scalia [58] subsequently published the first comparative study. Their patients underwent combined phacovitrectomy with ILM peeling and were advised to not lie face-up for 10 days. These patients were compared with a historical control group. The rationale for combined surgery includes an improved view of the retina, larger gas fill at the end of surgery, and avoidance of a second operation when cataract develops. Eighteen out of the 20 non-postured eyes $(90 \%)$ showed macular hole closure after 6 months compared with 11 out of 13 (85\%) in the postured group (no significant difference). Nineteen of the 20 eyes (90\%) showed an improvement of at least $0.3 \log$ MAR units in the non-postured group compared with 9 of 13 eyes (69\%) in the postured control group. The acknowledged limitations include the small number of patients, historical control group, lack of masking and lack of stage IV hole representation.

Tranos et al. [59] published the first prospectively controlled study comparing a postoperative 'no supine position' regime (similarly to Simcock and Scalia [58]) with a 10 -day FDP regime. They compared 16 non-postured with 25 FDP patients. Their cohort comprised mostly stage II and III holes, with only 6 patients with stage IV holes. All their cases underwent trypan blue-assisted ILM peeling. They found no significant difference in visual outcomes or primary anatomical closure between the postured $(22 / 25 ; 88 \%)$ and non-postured (14/16; $87.5 \%)$ groups. The only difference found was a significantly greater proportion of patients with posterior capsular cataract in the non-postured group 4 months postoperatively, and the authors suggested that phacovitrectomy be considered in non-postured macular hole surgery.

Guillaubey et al. [60] published the first multicentre randomised controlled trial. They analysed 150 eyes of 144 patients who were allocated to no FDP or 5 days of $8 \mathrm{~h}$ a day of FDP. All their patients underwent ILM peeling without staining. The study contains a rather heterogeneous group of patients and techniques; 62 patients underwent combined phacovitrectomy, whilst the rest did not. Different gas tamponades were used depending upon the size of the macular hole. $\mathrm{SF}_{6}$ was used in patients with 
holes of $<500 \mu \mathrm{m}, \mathrm{C}_{2} \mathrm{~F}_{6}$ for holes of $>500 \mu \mathrm{m}$, and $\mathrm{C}_{3} \mathrm{~F}_{8}$ for holes of $>800 \mu \mathrm{m}$. Notwithstanding these limitations, the authors found that patients with macular holes of $>400 \mu \mathrm{m}$ had worse anatomical outcomes if they did not undergo FDP. Thirty-nine of 41 (95.1\%) had anatomical closure 6 months postoperatively in the postured group compared with $31 / 39$ (79.5\%) in the non-postured group. They advised that although FDP may not be necessary for small macular holes, they would still recommend it for macular holes $>400 \mu \mathrm{m}$ in diameter.

In 2010, an attempt was undertaken at a meta-analysis of the comparative trials available [61]. With such heterogeneity of preoperative features, definitions of outcome, surgical techniques and follow-up periods, this was difficult. The conclusion of the analysis was that there seemed to be slightly increased macular hole closure rates with 5-10 days of FDP compared with posturing for $24 \mathrm{~h}$ or less, but that the difference was not statistically significant.

\section{Studies Analysing No FDP without ILM Peeling}

The most recent comparative trial was a randomised controlled parallel-assignment multicentre study [62]. This group of researchers included only macular holes of $<400 \mu \mathrm{m}$ diameter. Patients all underwent peeling of the epiretinal membrane, if present, but no staining or ILM peeling. They then had $17 \% \mathrm{C}_{2} \mathrm{~F}_{6}$ injection. Thirty-four patients were randomised to 10 days of FDP, whilst 35 were randomised to avoidance of supine positioning only for 10 days. The authors reported closure after 1 operation in 32 out of $34(94.1 \%)$ in the FDP group compared with 32 out of 35 (91.4\%) in the no-posturing group. The mean gain in visual acuity was 10.52 Early Treatment Diabetic Retinopathy Study letters in the FDP group and 10.23 in the alleviated group. The authors suggest that for small holes neither FDP nor peeling of the ILM are essential. Table 1 contains a summary of all comparative trials comparing no posturing with FDP.

\section{Conclusions}

The controversy over the importance of FDP after macular hole surgery continues. Studies are very heterogeneous, which makes comparison difficult. The various combinations of combined or separate cataract surgery, ILM peeling or no ILM peeling as well as different tamponade agents make it difficult to study individual risk factors in isolation. No studies have shown $100 \%$ closure, and a fuller understanding of the factors that influence outcome might enable surgeons to offer an individualised service based on the risk profile of each patient. The greatest risk factor for anatomical failure seems to be preoperative macular hole size [63]. At present, for small macular holes $(<400 \mu \mathrm{m})$, a streamlined service with minimal or no FDP may be acceptable. However, for larger holes, FDP appears to have a role [64]. The greatest obstacle to determining conclusively what the benefit of FDP is lies in the high success rate of macular hole surgery. With current closure rates of around 90\%, a study designed to look at differences in outcome needs to include very large case numbers. This is compounded by the need to stratify each arm according to hole size and combined or sequential cataract surgery. It may be beneficial to concentrate on larger macular holes, where a lower success rate may make a study more feasible. Even this would have to involve many centres working in collaboration over an extended period of time, and the costs of such an undertaking mean it is unlikely that we will have a definitive answer soon, so the controversy looks set to continue until sufficiently large and well-designed trials can be completed.

\section{Disclosure Statement}

The authors have no conflict of interest with the presented material.

\section{References}

$>1$ Binder S, Riss B: Advances in intraocular techniques in the treatment of retinal detachments arising from holes of the posterior pole. Br J Ophthalmol 1983;67:147-149.

$>2$ Harris MJ, de Bustros S, Michels RG: Treatment of retinal detachments due to macular holes. Retina 1984;4:144-147.

$\checkmark 3$ Gonvers M, Machemer R: A new approach to treating retinal detachment with macular hole. Am J Ophthalmol 1982;94:468-472.
4 Kelly NE, Wendel RT: Vitreous surgery for idiopathic macular holes: results of a pilot study. Arch Ophthalmol 1991;109:654-659.

5 Madreperla SA, Geiger GL, Funata M, de la Cruz Z, Green WR: Clinicopathologic correlation of a macular hole treated by cortical vitreous peeling and gas tamponade. Ophthalmology 1994;101:682-686.
-6 Tornambe PE, Poliner LS, Grote K: Macular hole surgery without face-down positioning: a pilot study. Retina 1997;17:179-185.

7 Azzolini C, Patelli F, Brancato R: Correlation between optical coherence tomography data and biomicroscopic interpretation of idiopathic macular hole. Am J Ophthalmol 2001; 132:348-355. 
8 Gass JD: Idiopathic senile macular hole: its early stages and pathogenesis. 1988. Retina 2003;23(suppl):629-639.

$>9$ Gaudric A, Haouchine B, Massin P, Paques M, Blain P, Erginay A: Macular hole formation: new data provided by optical coherence tomography. Arch Ophthalmol 1999;117: 744-751.

- 10 Tanner V, Chauhan DS, Jackson TL, Williamson TH: Optical coherence tomography of the vitreoretinal interface in macular hole formation. Br J Ophthalmol 2001;85:10921097.

11 Tornambe PE: Macular hole genesis: the hydration theory. Retina 2003;23:421-424.

-12 Gandorfer A, Scheler R, Haritoglou C, Schumann R, Nentwich M, Kampik A: Pathology of the macular hole rim in flatmounted internal limiting membrane specimens. Retina 2009;29:1097-1105.

-13 Bainbridge J, Herbert E, Gregor Z: Macular holes: vitreoretinal relationships and surgical approaches. Eye (Lond) 2008;22:13011309.

- 14 Al-Abdulla NA, Thompson JT, Sjaarda RN: Results of macular hole surgery with and without epiretinal dissection or internal limiting membrane removal. Ophthalmology 2004;111:142-149.

15 Brooks HL Jr: Macular hole surgery with and without internal limiting membrane peeling. Ophthalmology 2000;107:1939-1948, discussion 1948-1949.

$\checkmark 16$ Foulquier S, Glacet-Bernard A, Sterkers M, Soubrane G, Coscas G: Study of internal limiting membrane peeling in stage- 3 and -4 idiopathic macular hole surgery (in French). J Fr Ophtalmol 2002;25:1026-1031.

- 17 Sheidow TG, Blinder KJ, Holekamp N, Joseph D, Shah G, Grand MG, Thomas MA, Bakal J, Sharma S: Outcome results in macular hole surgery: an evaluation of internal limiting membrane peeling with and without indocyanine green. Ophthalmology 2003;110:1697-1701.

- 18 Christensen UC, Krøyer K, Sander B, Larsen M, Henning V, Villumsen J, la Cour M: Value of internal limiting membrane peeling in surgery for idiopathic macular hole stage 2 and 3: a randomised clinical trial. Br J Ophthalmol 2009;93:1005-1015.

$>19$ Lois N, Burr J, Norrie J, Vale L, Cook J, McDonald A, Boachie C, Ternent L, McPherson $\mathrm{G}$ : Internal limiting membrane peeling versus no peeling for idiopathic full-thickness macular hole: a pragmatic randomised controlled trial. Invest Ophthalmol Vis Sci 2011; 52:1586-1592.

20 Thompson JT, Glaser BM, Sjaarda RN, Murphy RP, Hanham A: Effects of intraocular bubble duration in the treatment of macular holes by vitrectomy and transforming growth factor- $\beta 2$. Ophthalmology 1994;101: 1195-1200.
21 Haut J, van Effenterre G, Ullern M, Chermet M: Surgical treatment of retinal detachment with macular holes by vitrectomy and silicone oil injections (in French, author's transl). J Fr Ophtalmol 1980;3:115-118.

22 Pertile G, Claes C: Silicone oil vs gas for the treatment of full-thickness macular hole. Bull Soc Belge Ophtalmol 1999;274:31-36.

23 Karia N, Laidlaw A, West J, Ezra E, Gregor MZ: Macular hole surgery using silicone oil tamponade. Br J Ophthalmol 2001;85:13201323.

24 Lai JC, Stinnett SS, McCuen BW: Comparison of silicone oil versus gas tamponade in the treatment of idiopathic full-thickness macular hole. Ophthalmology 2003;110:1170-1174

25 Goldbaum MH, McCuen BW, Hanneken AM, Burgess SK, Chen HH: Silicone oil tamponade to seal macular holes without position restrictions. Ophthalmology 1998;105: 2140-2147, discussion 2147-2148.

26 Tafoya ME, Lambert HM, Vu L, Ding M: Visual outcomes of silicone oil versus gas tamponade for macular hole surgery. Semin Ophthalmol 2003;18:127-131.

27 Green WR: The macular hole: histopathologic studies. Arch Ophthalmol 2006;124: 317-321.

28 Schubert HD, Kuang K, Kang F, Head MW, Fischbarg J: Macular holes: migratory gaps and vitreous as obstacles to glial closure. Graefes Arch Clin Exp Ophthalmol 1997; 235:523-529.

29 Berger JW, Brucker AJ: The magnitude of the bubble buoyant pressure: implications for macular hole surgery. Retina 1998;18:84-86, author reply 86-88.

30 Thompson JT, Smiddy WE, Glaser BM, Sjaarda RN, Flynn HW Jr: Intraocular tamponade duration and success of macular hole surgery. Retina 1996;16:373-382.

31 Foster WJ, Chou T: Physical mechanisms of gas and perfluoron retinopexy and sub-retinal fluid displacement. Phys Med Biol 2004; 49:2989-2997.

32 Couvillion SS, Smiddy WE, Flynn HW Jr, Eifrig CW, Gregori G: Outcomes of surgery for idiopathic macular hole: a case-control study comparing silicone oil with gas tamponade. Ophthalmic Surg Lasers Imaging 2005;36:365-371.

33 Parver LM, Lincoff H: Mechanics of intraocular gas. Invest Ophthalmol Vis Sci 1978; 17:77-79.

34 Williamson TH: Vitreoretinal Surgery. Berlin, Springer, 2007, vol xvi, p 227.

35 Waterman A: Randomised Controlled Trial to Evaluate the Effects of Two Face-Down Posturing Regimes following Vitreo-Retinal Surgery with Internal Gas Tamponade; MSc dissertation, University of Manchester, Manchester, 2002.

36 Jumper JM, Gallemore RP, McCuen BW 2nd, Toth CA: Features of macular hole closure in the early postoperative period using optical coherence tomography. Retina 2000;20:232237.
37 Satchi K, Patel CK: Posterior chamber compartments demonstrated by optical coherence tomography, in silicone-filled eyes, following macular hole surgery. Clin Exp Ophthalmol 2005;33:619-622.

38 Muqit MM, Akram I, Turner GS, Stanga PE: Fourier-domain optical coherence tomography imaging of gas tamponade following macular hole surgery. Ophthalmic Surg Lasers Imaging 2010;41(online):e1-e6.

39 Eckardt C, Eckert T, Eckardt U, Porkert U, Gesser C: Macular hole surgery with air tamponade and optical coherence tomographybased duration of face-down positioning. Retina 2008;28:1087-1096.

40 Gesser C, Eckert T, Eckardt U, Porkert U, Eckardt C: Macular hole surgery with air tamponade: does air suffice for short-term tamponade? (in German). Ophthalmologe 2010;107:1043-1050.

41 Krohn J: Duration of face-down positioning after macular hole surgery: a comparison between 1 week and 3 days. Acta Ophthalmol Scand 2005;83:289-292.

42 Harker R, McLaughlan R, MacDonald H, Waterman C, Waterman HA: Endless nights: patients' experiences of posturing face-down following vitreoretinal surgery. Ophthalmic Nurs 2002;6:11-15.

43 Waterman H, Harker R, MacDonald H, McLaughlan R, Waterman C: Advancing ophthalmic nursing practice through action research. J Adv Nurs 2005;52:281-290.

44 Ellis JD, Malik TY, Taubert MA, Barr A, Baines PS: Surgery for full-thickness macular holes with short-duration prone posturing: results of a pilot study. Eye (Lond) 2000; 14:307-312

45 Waterman $\mathrm{H}$, Harker R, MacDonald $\mathrm{H}$, McLaughlan R, Waterman C: Evaluation of an action research project in ophthalmic nursing practice. J Adv Nurs 2005;52:389398

-46 Madgula IM, Costen M: Functional outcome and patient preferences following combined phaco-vitrectomy for macular hole without prone posturing. Eye (Lond) 2008;22:10501053.

-47 Verma D, Jalabi MW, Watts WG, Naylor G: Evaluation of posturing in macular hole surgery. Eye (Lond) 2002;16:701-704.

48 Krohn J: Topical medication interferes with face-down positioning after macular hole surgery. Acta Ophthalmol Scand 2003;81: 226-229.

49 Sutter FK, Smorgon A, McClellan K: Acute angle closure in the fellow eye as a complication of prone positioning after vitreoretinal surgery. Arch Ophthalmol 2003;121:1057.

50 Ciulla TA, Frederick AR Jr, Kelly C, Amrein R: Postvitrectomy positioning complicated by ulnar nerve palsy. Am J Ophthalmol 1996; 122:739-740.

51 Treister G, Wygnanski T: Pressure sore in a patient who underwent repair of a retinal tear with gas injection. Graefes Arch Clin Exp Ophthalmol 1996;234:657-658. 
52 Castro Navarro J, González-Castaño C: Macular hole surgery with and without internal limiting membrane peeling (in Spanish). Arch Soc Esp Oftalmol 2003;78:159-164.

-53 Ben Simon GJ, Desatnik H, Alhalel A, Treister G, Moisseiev J: Retrospective analysis of vitrectomy with and without internal limiting membrane peeling for stage 3 and 4 macular hole. Ophthalmic Surg Lasers Imaging 2004;35:109-115.

54 Dhawahir-Scala FE, Maino A, Saha K, Mokashi AA, McLaughlan R, Charles S: To posture or not to posture after macular hole surgery. Retina 2008;28:60-65.

55 Isomae T, Sato Y, Shimada H: Shortening the duration of prone positioning after macular hole surgery: comparison between one week and one day (in Japanese). Nippon Ganka Gakkai Zasshi 2001;105:167-170.
56 Rubinstein A, Ang A, Patel CK: Vitrectomy without postoperative posturing for idiopathic macular holes. Clin Exp Ophthalmol 2007;35:458-461.

57 Merkur AB, Tuli R: Macular hole repair with limited nonsupine positioning. Retina 2007; 27:365-369.

58 Simcock PR, Scalia S: Phacovitrectomy without prone posture for full-thickness macular holes. Br J Ophthalmol 2001;85:1316-1319.

59 Tranos PG, Peter NM, Nath R, Singh M, Dimitrakos S, Charteris D, Kon C: Macular hole surgery without prone positioning. Eye (Lond) 2007;21:802-806.

60 Guillaubey A, Malvitte L, Lafontaine PO, Jay N, Hubert I, Bron A, Berrod JP, CreuzotGarcher C: Comparison of face-down and seated position after idiopathic macular hole surgery: a randomized clinical trial. Am J Ophthalmol 2008;146:128-134.
61 Tatham A, Banerjee S: Face-down posturing after macular hole surgery: a meta-analysis. Br J Ophthalmol 2010;94:626-631.

62 Tadayoni R, Vicaut E, Devin F, CreuzotGarcher C, Berrod JP, le Mer Y, Korobelnik JF, Aout M, Massin P, Gaudric A: A randomized controlled trial of alleviated positioning after small macular hole surgery. Ophthalmology 2011;118:150-155.

63 Ullrich S, Haritoglou C, Gass C, Schaumberger M, Ulbig MW, Kampik A: Macular hole size as a prognostic factor in macular hole surgery. Br J Ophthalmol 2002;86:390393.

64 Gaudric A: Macula hole surgery: simple or complex? Am J Ophthalmol 2009;147:381383 